\title{
Pulse oximetry during ketamine anaesthesia in war conditions
}

\author{
P. Pesonen MD
}

\begin{abstract}
Ketamine anaesthesia with spontaneous breathing of air is a common method of anaesthesia in Red Cross hospitals for war wounded. Arterial oxygen saturation of 65 patients was measured with a portable pulse oximeter during the anaesthesia and the first 30 min of recovery. The patients were young (12-47 yr). haemodynamically stable and underwent peripheral surgery. Fiffy-seven measurements were free from artefacts and were analyzed. The results showed that during induction six patients (11\%) had a brief period (40-420 sec) of oxygen saturation under $90 \%$. Two of these patients showed signs of upper airway obstruction and four breathed normally. During maintenance one patient had short periods $(40-80 \mathrm{sec})$ of saturation under $90 \%$, when he snored. No periods of desaturation occurred during the recovery period. It is concluded that arterial oxygen saturation remained acceptable when patients breathed air during ketamine anaesthesia.
\end{abstract}

L'anesthésie à la kétamine associée à une respiration spontanée à l'air est une méthode d'anesthésie commune dans les hôpitaux de la Croix-Rouge pour les blessés de guerre. La saturation artérielle en oxygène a été mesurée chez 65 patients à l'aide d'un saturomètre portatif durant l'anesthésie et les 30 premières minutes de récupération. Il s'agissait de patients jeunes (12 à 47 ans) hémodynamiquement stables et qui subissaient une chirurgie périphérique. Cinquante-sept mesures ne contenaient pas d' artéfacts et ont été analysées. Les résultats ont démontré que durant l' induction, six patients (11\%) ont eu une saturation en oxygène au-dessous de $90 \%$ durant une courte période (40 à 420 secondes). Deux de ces patients ont montré des signes d'obstruction des voies respiratoires supérieures et quatre respiraient normalement. Durant le maintien de l'anesthésie, un patient a eu des saturations au-dessous de 90\%

\section{Key words}

ANAESTHETICS, INTRAVENOUS: ketamine;

MEASUREMENT TECHNIQUES: pulse oximetry;

SURGERY: War.

From the International Committce of the Red Cross, 19 Avenue de la Paix, 1202 Geneve, Switzerland.

Address correspondence to: Dr. P. Pcsonen, Raisiontie 4 D 38, 00280 Helsinki, Finland.

Accepted for publication 7th March, 1991 . pendant une courte période (40 à 80 secondes), lorsqu'il ronflait. Il n'y eut aucune période de désaturation durant la période de récupération. Nous concluons que la saturation artérielle en oxygène est demeurée acceptable lorsque les patients respiraient de l'air, durant une anesthésie à la kétamine.

Ketamine anaesthesia is easy and safe to administer. It has been recommended for difficult and unusual circumstances because it has the advantages of cardiovascular stimulation and preservation of breathing. ${ }^{1}$ The International Committee of the Red Cross (ICRC) treats victims of armed conflicts in developing countries. The hospitals are designed to give simple and definitive treatment to a large number of war-wounded. The anaesthetist may work unaided with a rapid turn-over of patients. Monitoring equipment is basic (stethoscope and sphygmomanometer) and the quality of postoperative care is variable. In these circumstances ketamine anaesthesia is invaluable. ${ }^{2}$

Hypoxia is a potential risk of ketamine anaesthesia when supplementary oxygen is not administered routinely. This is of particular concern in a field hospital where war-wounded patients frequently become anaemic. A pulse oximeter was lent to the author by the manufacturer to detect hypoxia associated with ketamine anaesthesia in war-wounded patients. This paper decribes its use under field conditions.

\section{Methods}

Sixty-five war-wounded patients of mixed ethnic origin received ketamine anaesthesia and had their arterial oxygen saturation monitored with a portable pulse oximeter (Satlite Trans, Datex Instrumentarium Corporation; Helsinki, Finland). They were haemodynamically stable and did not have penetrating injuries of their chest, abdomen or central nervous system. Forty-nine patients were Afghans and sixteen Cambodians. Sixty (92\%) were male. Estimated ages ranged from 12 to $47 \mathrm{yr}$ (mean 27 yr). Estimated weights ranged from 40 to $80 \mathrm{~kg}$ (mean 61 $\mathrm{kg}$ ). The range of measured haemoglobin concentrations was 7.1-15.5 (mean 11.2) $\mathrm{g} \cdot \mathrm{dl}^{-1}$.

Patients were given, iv, atropine $0.01 \mathrm{mg} \cdot \mathrm{kg}^{-1}$ as an 
TABLE I Surgical procedures

\begin{tabular}{lc}
\hline Wound excision & $31(48 \%)$ \\
Amputation & $1(2 \%)$ \\
Application/removal of extemal fixator & $3(5 \%)$ \\
Dressing & $5(8 \%)$ \\
Skin-grafting & $12(18 \%)$ \\
Delayed primary suture & $13(12 \%)$ \\
\hline
\end{tabular}

TABLE II Patient positions

\begin{tabular}{lc}
\hline Supine & $52(80 \%)$ \\
Lateral & $10(15 \%)$ \\
Prone & $3(5 \%)$ \\
\hline
\end{tabular}

antisialagogue and diazepam $0.1 \mathrm{mg} \cdot \mathrm{kg}^{-1}$ to reduce postoperative delirium. Anaesthesia was induced with intravenous ketamine $2 \mathrm{mg} \cdot \mathrm{kg}^{-1}$ which was injected over at least one minute to reduce the chance of apnoea or upper airway obstruction. During the operation ketamine was given as an infusion to reduce total dosage and to encourage rapid recovery. The infusion contained 1 $\mathrm{mg} \cdot \mathrm{ml}^{-1}$ of ketamine in $5 \%$ dextrose and was adjusted manually to deliver between 20 to $70 \mu \mathrm{g} \cdot \mathrm{kg}^{-1} \cdot \mathrm{min}^{-1}$. In the event of patient movement or phonation a bolus of $0.3 \mathrm{mg} \cdot \mathrm{kg}^{-1}$ of ketamine was given and the infusion rate was increased. The patients breathed air spontancously and no artificial airway was used. The airway was maintained by careful positioning of the head and jaw thrust.

The infusion was stopped three to five minutes before the end of the surgery. The patients were taken by stretcher to their wards and recovered in the lateral or semi-lateral position. The period of continous pulse oximetry monitoring included induction, operation and the first $30 \mathrm{~min}$ of recovery. The oximeter recorded arterial oxygen saturation continuously and stored an average value for each ten-second period. Periods of saturation less than $90 \%$ and less than $80 \%$ were timed from the memory display and concurrent patterns of breathing were noted.

\section{Results}

Pulse oximeter reading before anaesthesia ranged from 94\% to $99 \%$ (mean $98 \%$ ). The surgical procedures are presented in Table I and the positions of the patients in Table II.

Data from eight of the 65 patients were discarded because a low quality of signal or movement artefact interrupted the recordings. Of the 57 remaining patients, six $(11 \%)$ showed a period of saturation less than $90 \%$. These patients had a desaturation at induction as shown in Table III. Four of them had transient desaturation with
TABLE III Arterial oxygen saturation $<90 \%$ at induction (saturation $<80 \%$ in parenthesis)

\begin{tabular}{rlll}
\hline Patient number & Duration (sec) & Pattern of breathing & Position \\
\hline 1 & 40 & Normal & Lattral \\
5 & $300(100)$ & Snoring & Supine \\
10 & 280 & Normal & Supine \\
14 & 40 & Normal & Supine \\
16 & $420(40)$ & Snoring & Supine \\
32 & 60 & Normal & Supine \\
\hline
\end{tabular}

apparent normal breathing. Two had longer periods of desaturation associated with snoring, during which there were brief periods of oxygen saturation less than $80 \%$. One of the above patients also had three periods of saturation between $80-90 \%$ when he snored during surgery. These lasted 40,80 , and $40 \mathrm{sec}$. No other periods of desaturation occurred during the maintenance of anaesthesia.

No patient had low oxygen saturation during the postoperative monitoring.

\section{Discussion}

The pulse oximeter is a rare luxury in a field hospital and it was brought to the ICRC hospitals for research purposes only. Oxygen is available in all ICRC operating theatres, but its supply can be a logistic problem and therefore it is used sparingly. Ketamine anaesthesia for a generally fit patient is usually conducted without supplementary oxygen and it is assumed that adequate oxygenation is maintained. This study allowed this assumption to be examined.

Most patients had normal oxygenation throughout anaesthesia: six of 57 had brief periods of mild hypoxia. Desaturation occurred mainly at induction and was associated with snoring and normal breathing. Apnoea did not occur. Trivial airway problems were common at induction but were mostly dealt with before saturation deteriorated. More persistent snoring, predictably, caused hypoxia until manipulation of the jaw cleared the airway. Artificial airways were not used because patients tolerate them poorly during ketamine anaesthesia. Brief oxygen desaturation also occurred when breathing was normal.

Once the effect of induction had settled and the ketamine infusion was started, the oxygen saturation was remarkably stable and good. Postoperatively, when patients were often left unattended, all patients showed good saturation.

It is concluded that ketamine-air anaesthesia is suitable for use in a field hospital. Episodes of desaturation, which were not severe, occurred at a time when the patient was cared for by the anaesthetist. To maintain good oxygena- 
tion, it is essential to induce anaesthesia very slowly and give constant attention to the airway.

\section{Acknowledgements}

The author thanks the International Committee of the Red Cross and the Finnish Red Cross for permission to publish this study, the Datex Instrumentarium for providing the pulse oximeter and Robin Coupland, FRCS, for his assistance in preparing the manuscript.

\section{References}

1 White PF, Way WL, Trevor AJ. Ketamine - its pharmacology and therapeutic uses. Anesthesiology 1982; 56: 119-36.

2 Bion J. An anacsthetist in a camp for Cambodian refugees. Anaesthesia 1983; 38: 798-801. 